\title{
Female-enriched and thermosensitive expression of steroidogenic factor-1 during gonadal differentiation in Pleurodeles waltI
}

\author{
S Kuntz, D Chardard, C-I Ko, H Dumond, M Ducatez, M Callier, S Flament and A Chesnel \\ EA 3442: Aspects Cellulaires et Moléculaires de la Reproduction et du Développement, Université Henri Poincaré-Nancy 1, Faculté des Sciences, BP239, Boulevard des \\ Aiguillettes, 54506 Vandœuvre lès nancy CEDEX, France
}

(Requests for offprints should be addressed to S Flament; Email: Stephane.Flament@scbiol.uhp-nancy.fr)

\begin{abstract}
In the urodele amphibian Pleurodeles walt, sex differentiation is genetically controlled, that is, ZZ male vs ZW female, but may be influenced by temperature, which induces a female-to-male sex reversal. We investigated whether steroidogenic factor 1 (SF-1) could be involved in Pleurodeles sex differentiation or in temperature-dependent sex reversal by cloning a Pleurodeles SF-1 cDNA and examining its developmental expression. The 468-amino-acid deduced protein is highly conserved in comparison with other species. In ZZ and ZW control larvae, SF-1 mRNA is detected at the first stage of the thermosensitive period (TSP) in the gonad-mesonephros-interrenal complex (GMI). By the end of TSP at stage 55, SF-1 is expressed in the gonad (Gd) and in the mesonephros-interrenal (MI) both in ZZ and ZW larvae. During this stage, a transient, ZW-specific increase of SF-1 transcription occurs not only in Gd but also in $\mathrm{MI}$, this increase starting earlier in Gd than in MI. Therefore, in $P$. waltl, an SF-1 upregulation occurs after the onset of the ovarian-specific increase of aromatase mRNA expression. At the end of metamorphosis, the SF-1 transcription level in $\mathrm{Gd}$ and $\mathrm{Ml}$ is nearly the same in both ZZ and ZW larvae. Besides, after long-term heat treatment leading to sex reversal, SF-1 mRNA upregulation is not observed in ZW larvae, in either Gd or MI. However, SF-1 expression is not decreased after a 48-h heat shock applied at the end of the TSP, suggesting that temperature has no inhibitory effect by itself in long-term heat treatment. Estradiol benzoate treatments show that, at the end of the TSP, SF-1 gene transcription could be controlled by the estrogen level. This is in accordance with the female-enriched SF-1 expression and the decreased SF-1 expression following long-term, sex-reversing heat treatment, which is known to decrease aromatase expression and activity. Thus, it is unlikely that SF-1 is directly involved in Pleurodeles temperature-dependent sex reversal.
\end{abstract}

Journal of Molecular Endocrinology (2006) 36, 175-186

\section{Introduction}

The steroidogenic factor-1 gene (SF-1) encodes a nuclear orphan receptor belonging to the nuclear receptor superfamily (Lala et al. 1992, Whitfield et al. 1999). In various species, $\mathrm{SF}-1$ is known to be expressed in several tissues involved in steroidogenesis and/or reproduction, such as the adrenal glands in mammals and corresponding organs in other species, such as the interrenal tissue in amphibians (Mayer et al. 2002) as well as brain and gonad (Val et al. 2003). SF-1 plays a key role in the development of both the hypothalamic-pituitary-adrenal and hypothalamic-pituitary-gonadal axes (Ikeda et al. 1993), since mice with a SF-1 gene homozygous disruption show complete adrenal and gonadal agenesis and ventromedial hypothalamus dysgenesis (Luo et al. 1994, Ikeda et al. 1995, Shinoda et al. 1995). A failure of gonad and adrenal development has also been detected in a human case of male-to-female sex reversal exhibiting a heterozygote mutation in the SF-1 gene (Achermann et al. 1999). Furthermore, the SF-1 ${ }^{(-1-)} \mathrm{XY}$ mice have a female phenotype (Luo et al. 1994). These results agree with an early expression of SF-1 in the genital ridges of both sexes throughout the undifferentiated stage (Ikeda et al. 1994), leading to adrenal formation and gonadal differentiation (Schnabel et al. 2003). At a later stage of development, as histologic sex differentiation of the gonad begins, several vertebrate species exhibit a sexually dimorphic gonadal expression of SF-1 in their developing gonads. A higher level of SF-1 mRNA is found in the male differentiating gonad in mouse (Ikeda et al. 1994), rat (Hatano et al. 1994), man (Hanley et al. 2000), pig (Pilon et al. 1998) and turtle (Wibbels et al. 1998), whereas an opposite situation is observed in chicken (Smith et al. 1999), alligator (Western et al. 2000) and American bullfrog (Mayer et al. 2002). In mammals, SF-1 controls the expression of many enzymes required for steroid hormone production, including aromatase (Parker \& Schimmer 2002). For instance, in rat and man, SF-1 binds to the aromatase promoter and activates its transcription (Lynch et al. 1993, Michael et al. 1995). SF-1-binding sites have also 
been identified in the promoter region of aromatase gene in chicken (Kudo et al. 1996), Xenopus (Akatsuka et al. 2005), and many teleost fishes (Tanaka et al. 1995, Tong \& Chung 2003, Yoshiura et al. 2003, Gardner et al. 2005). Alternatively, estrogen could also control SF-1 transcription, as suggested in the red-eared slider turtle model (Fleming \& Crews 2001), in which estradiol treatment was shown to produce SF-1 upregulation, although it was not proved that the effect was direct or indirect.

In the urodele amphibian Pleurodeles waltl, steroid hormones play a role in sex differentiation since the application of estradiol to the rearing water during a hormone-sensitive period induces $\mathrm{ZZ}$ genetic male larvae to differentiate into functional neofemales (Gallien 1951). Moreover, a similar treatment performed with an aromatase inhibitor can induce a complete female-tomale sex reversal (Chardard \& Dournon 1999), demonstrating that the aromatase enzymatic complex plays a very important part in the process of female differentiation (Kuntz et al. 2003a). Indeed, aromatase activity measurements in gonad revealed up to 40-fold higher activity in $\mathrm{ZW}$ larvae than in their $\mathrm{ZZ}$ counterparts at the onset of ovarian differentiation (Chardard et al. 1995). However, the gonadal level of endogenous aromatase transcripts in ZW larvae was only 1.5-fold higher than in ZZ, suggesting the involvement of an unknown post-transcriptional regulation (Kuntz et al. 2003b).

Temperature can also interfere with the ZZ/ZW genetic sex determination and sex ratio, since ZW larvae reared at $32{ }^{\circ} \mathrm{C}$ during the thermosensitive period (TSP) differentiate into functional neomales (Dournon \& Houillon 1984). The masculinizing temperature was shown to inhibit aromatase activity (Chardard et al. 1995) and could act as a direct or indirect repressor of estrogen synthesis, since estradiol benzoate can counteract the masculinizing effect of a high rearing temperature (Zaborski 1986).

Since the aromatase gene is differentially expressed during sexual differentiation and considering that this expression can be indirectly affected by temperature, we focused our attention on SF-1, a known potential regulator of aromatase. We first isolated SF-1 cDNA containing a putative open reading frame. Expression analysis during gonadal development of $\mathrm{ZZ}$ and $\mathrm{ZW}$ larvae revealed the presence of SF-1 mRNA early during the TSP in the gonad-mesonephros-interrenal complex (GMI), either when aromatase mRNA is present in low amounts in the undifferentiated gonad (Gd) or at the time of aromatase expression increase in ZW larvae. A transient, female-specific upregulation of SF-1 expression was observed at the end of TSP, not only in Gd but also in the mesonephros-interrenal (MI), suggesting a role of SF-1 in the differentiating ovary and in mesonephric or interrenal steroid synthesis. Amounts of SF-1 mRNAs were significantly decreased in ZW larvae subjected to long-term sex-reversing heat treatment, in either Gd or MI, but not in the brain. However, these changes in SF-1 gene expression, rather than being directly regulated by temperature during the TSP, seem to be related to changes in aromatase mRNA expression and activity leading to low estrogen levels. Indeed, estradiol benzoate treatments of $\mathrm{ZZ}$ larvae clearly induce upregulation of SF-1 mRNA expression. Therefore, SF-1 does not appear to be directly involved in temperature-dependent sex-reversal in Pleurodeles.

\section{Materials and methods}

\section{Animals}

Adult $P$. waltl were reared in fresh water at a controlled temperature of $20 \pm 2{ }^{\circ} \mathrm{C}$ in our laboratory (standard $\mathrm{ZW}^{20}$ and $\mathrm{ZZ}^{20}$ ). The $\mathrm{ZW}$ or $\mathrm{ZZ}$ sexual genotype was determined by electrophoretic patterning of the two $\mathrm{W}$ - and/or Z-linked peptidase-1 isoforms, as described previously (Chardard et al. 1995). Developmental stages were determined by macroscopic observation according to Gallien and Durocher (1957). Stage 55 lasts about 2 months and was chronologically subdivided into stage 55 , stage $55+15$ days $\left(55^{15 \mathrm{~d}}\right)$ and stage $55+30$ days $\left(55^{30 d}\right)$. The TSP from stage 42 to 54 is defined as the period while $\mathrm{ZW}$ larvae must be reared at $32{ }^{\circ} \mathrm{C}$ in order to obtain 100\% sex reversal (Dournon \& Houillon 1984). Heat treatment of $\mathrm{ZW}$ larvae was run at $32{ }^{\circ} \mathrm{C}\left(\mathrm{ZW}^{32}\right)$ during the TSP while other $\mathrm{ZW}$ or $\mathrm{ZZ}$ larvae were maintained at $20 \pm 2{ }^{\circ} \mathrm{C}$ as a control $\left(Z^{20}, Z^{20}\right)$. Heat shocks of $32{ }^{\circ} \mathrm{C}$ were applied to $\mathrm{ZW}$ larvae $\left(\mathrm{ZW}^{\mathrm{h} s}\right)$ for $48 \mathrm{~h}$ at stages 55 and $55^{30 \mathrm{~d}}$. Hormonal treatment was run by rearing $\mathrm{ZZ}$ larvae at stages 55 and $55^{30 \mathrm{~d}}$ for $48 \mathrm{~h}$ in fresh water containing estradiol benzoate $(100 \mu \mathrm{g} / \mathrm{l})$. Before dissection, animals were anesthetized in a solution of benzocaine $(0.03 \%)$, and the brain, Gd, MI or GMI was dissected for further analysis. Due to their small size, Gd could not be isolated from the MI before stage $55^{15 \mathrm{~d}}$.

\section{SF-1 cDNA isolation}

Total RNA $(1 \mu \mathrm{g})$ from adult testis was reverse transcribed with oligo $\left(\mathrm{dT}_{15}\right)$ primers and Superscript II mouse Moloney leukemia virus (MMLV) reverse transcriptase (Invitrogen). An aliquot of the reaction was amplified by PCR with the degenerated primers Sf1, Sf2 and Sf4 (Table 1). The amplification was performed in the presence of $0 \cdot 1$ unit Taq DNA polymerase (Invitrogen) in PGR buffer containing $25 \mathrm{mM}$ of each dNTP and $3.5 \mathrm{mM} \mathrm{MgCl}_{2}$. A $60{ }^{\circ} \mathrm{C}$ to $40{ }^{\circ} \mathrm{C}$ touchdown PGR program was run at $94^{\circ} \mathrm{C}$ for $3 \mathrm{~min}$ followed by 20 cycles at $94^{\circ} \mathrm{C}$ for $1 \mathrm{~min}$, annealing for $1 \mathrm{~min}$ and $72^{\circ} \mathrm{C}$ for $1 \mathrm{~min}$. Amplification was then 
Table 1 List of PCR primers used

\begin{tabular}{|c|c|c|}
\hline \multirow[b]{2}{*}{ Gene $e^{(*)}$} & \multirow[t]{2}{*}{ Name } & Primer sequence \\
\hline & & \\
\hline SF-1 & Sf 1 & 5'-TGYAARGGITTYTTYAARMGIAC-3' \\
\hline SF-1 & $\mathrm{Sf} 2$ & 5'-AARTTYGGICCIATGTAYAA-3' \\
\hline $\mathrm{SF}-1$ & Sf 4 & 5'-TCISWCCARCARTTYTG-3' \\
\hline $\mathrm{SF}-1$ & Sf1-5R & 5'CTGGTCGGCCATCTTGCACATGAGGCC-3' \\
\hline SF-1 & Sf1-3R & 5'-CTGGAAGCGGTGCGGGCAGACAGG-3' \\
\hline SF-1 & Sf $1-1$ & 5'-GGGTACACCTACCCACACTT-3' \\
\hline SF-1 & Sf1-5 & 5'-TCTTGGCCTGTGACCAGGAG-3' \\
\hline Aromatase & Arom-1 & 5'-ATTGCAGCACCTGACACGAT-3' \\
\hline Aromatase & Arom-6 & 5'-TTGTTCTGTACATTCTCTAA-3' \\
\hline GAPDH & fwd & 5'-ACTACAAAGGACTAGGTCAGG-3' \\
\hline GAPDH & rev & 5'-CCGGTATTGCACTCAACGACC-3' \\
\hline
\end{tabular}

${ }^{*}$ ) Aromatase and GAPDH primers were used as a control in RT-PCR analysis of SF-1 expression.

pursued with 30 cycles at $94{ }^{\circ} \mathrm{C}$ for $1 \mathrm{~min}, 40{ }^{\circ} \mathrm{C}$ for $1 \mathrm{~min}$ and $72^{\circ} \mathrm{C}$ for $1 \mathrm{~min}$. Two independent PCR products of 657 and $800 \mathrm{bp}$ were obtained by using two different sets of primers, Sf2/Sf4 and Sf1/Sf4 respectively (Table 1). After separation on agarose gel electrophoresis, the expected fragments were purified, inserted into the plasmid pCR2 (Invitrogen) and transfected in $E$. coli INV $\alpha$ strain (Invitrogen), and both were sequenced (Genome Express, Meylan, France).

The $5^{\prime}$ and $3^{\prime}$ rapid amplification of cDNA ends (RACE) system (SMART RACE cDNA amplification kit; Clontech) was used to amplify the $5^{\prime}$-end and $3^{\prime}$-end of SF-1 cDNA synthesized from $1 \mu \mathrm{g}$ total RNA isolated from adult testis according to the manufacturer's instructions. PCR was performed with 1 unit Taq DNA polymerase (Advantage 2 Polymerase Mix; Clontech) and specific primer for each amplification in the $5^{\prime}$-end and 3 '-end regions ( $\mathrm{Sfl}-5 \mathrm{R}$ and $\mathrm{Sfl}-3 \mathrm{R}$ respectively) (Table 1). The reaction mixture was heated at $94{ }^{\circ} \mathrm{C}$ for $3 \mathrm{~min}$ and amplified for the first five cycles as follows: $94{ }^{\circ} \mathrm{C}$ for $30 \mathrm{~s}$ and $72{ }^{\circ} \mathrm{C}$ for $3 \mathrm{~min}$. The next five cycles were $94^{\circ} \mathrm{C}$ for $30 \mathrm{~s}, 70{ }^{\circ} \mathrm{C}$ for $30 \mathrm{~s}$ and $72{ }^{\circ} \mathrm{C}$ for $3 \mathrm{~min}$. The remaining 30 cycles of $\mathrm{PCR}$ were carried out at $94{ }^{\circ} \mathrm{C}$ for $30 \mathrm{~s}, 68{ }^{\circ} \mathrm{C}$ for $30 \mathrm{~s}$ and $72{ }^{\circ} \mathrm{C}$ for $3 \mathrm{~min}$, with a final extension at $72{ }^{\circ} \mathrm{C}$ for $10 \mathrm{~min}$. Two fragments of 0.9 and $1.2 \mathrm{~kb}$, isolated from the $5^{\prime}$ and $3^{\prime}$ regions respectively, were purified (QiaEX II Kit; Qiagen), inserted into the plasmid pGEM-T Easy (Promega), transfected into $E$. coli TG1 strain and sequenced (Genome Express).

\section{Reverse transcription-polymerase chain reaction (RT-PCR) analyses}

The detailed protocol for RT has been previously described (Kuntz et al. 2003b). Total RNA was extracted from dissected tissues with TRIzol reagent (Invitrogen) and quantified (BioPhotometer; Eppendorf, Le Pecq,
France). Total RNA (1 $\mu \mathrm{g})$ was reverse transcribed with random hexanucleotide primers and 100 units MMLV reverse transcriptase in a total volume of $25 \mu \mathrm{l}$. A $2 \mu \mathrm{l}$ aliquot of resultant cDNA was PGR amplified with $0 \cdot 1$ unit of Taq DNA Polymerase (Invitrogen) in PCR buffer containing $25 \mathrm{mM}$ of each dNTP, $2.5 \mathrm{mM} \mathrm{MgCl}_{2}$ and $0 \cdot 4 \mathrm{pM}$ of each primer in a total volume of $25 \mu \mathrm{l}$. RTPCR analyses were performed on ' $n$ ' samples ( $n$ is given in figures and tables), each sample comprising a pool of four or five individuals. Specific primers for $P$. waltl were $\mathrm{Sfl}-1$ and Sf1-5, leading to a PCR product of 462 bp in length. The specific primers for the aromatase cDNA were Arom- 1 and Arom-6, and the resulting PCR product was $510 \mathrm{bp}$ in length. All the PCR products encompassed one exon/intron boundary based on other vertebrate gene alignments (not shown). To ensure that the RNA was not degraded and to prevent poor transcription quality, GAPDH cDNA was used as a control (see primer sequence in Table 1). The PCR conditions were 30-s denaturation at $94{ }^{\circ} \mathrm{C}$, and 30 -s annealing and 2-min elongation at $72{ }^{\circ} \mathrm{C}$, and led to a $290 \mathrm{bp}$ fragment. Annealing temperatures were $52{ }^{\circ} \mathrm{C}$ for GAPDH and aromatase primers, and $60{ }^{\circ} \mathrm{C}$ for $\mathrm{SF}-1$ primers. We performed 35 cycles for qualitative analyses and 26 or 28 cycles for semiquantitative analyses in $\mathrm{Gd}$ and brain respectively. PGR products were then separated in a $1 \%$ agarose gel and transferred to nylon membrane (Hybond-N, Amersham) before hybridization with DIG-labeled probes and detection by chemoluminescence under previously described conditions (Kuntz et al. 2003b). Semiquantitative RT-PCR analysis was performed by running 28 or 30 PCR cycles for mRNA from Gd or MI respectively. PCR products were separated in agarose gel and compared with GAPDH level. In all cases, amplification was verified to take place in the linear phase of the PCR, and the intensity of the hybridization signal or agarose gel band was normalized to GAPDH by using the GelDoc 2000 (Bio-Rad) and a software package (Quantity One v.4·3·1; Bio-Rad). 


\section{Statistical analysis}

The relative intensities of $\mathrm{SF}-1$ and aromatase mRNAs were compared after normalization to GAPDH mRNA levels. The results are expressed as mean \pm S.E.M. of several measurements performed on different pools for each group, as indicated in the text. The variation of relative SF-1 mRNA expression between sexes $\left(Z^{20}\right.$ and $\mathrm{ZW}^{20}$ groups) was analyzed by comparison of means with Student's $t$-test. The statistical significance of SF-1 and aromatase mRNA expression regarding to temperature $\left(\mathrm{ZW}^{32}\right.$ or $\mathrm{ZW}^{\text {hs }}$ and $\mathrm{ZW}^{20}$ groups) was estimated by comparing means of the relative SF-1 or aromatase mRNA expression from each group by analysis of variance (one-way ANOVA) followed by the Bonferroni multiple comparison procedure with SPSS 11.5 software (SPSS Inc., Chicago, IL, USA).

\section{Results}

\section{SF-1 is conserved in $P$. waltI}

Pleurodeles SF-1 cDNA sequence (accession no. AY540336, not shown) was obtained by RT-PCR from total RNA extracted from adult testis. Two independent clones of 657 and $800 \mathrm{bp}$ were obtained by degenerated PCR, using different set of primers (Table 1). Then, 5' and $3^{\prime}$ RACE was performed in order to isolate the full-length SF-1 mRNA containing a putative $1407 \mathrm{bp}$ open reading frame. The deduced amino-acid sequence was compared with SF-1 sequences from several species: Rana rugosa, Trachemys scripta, chicken, mouse and man (Fig. 1). The putative encoded polypeptide is composed of 468 amino acids and is related to that of $R$. rugosa although slightly longer than that of $T$. scripta (466 residues), mouse (462 residues) and man (461 residues). Overall sequence identity with T. scripta was $81 \%$, with R. rugosa $79 \%$, and with mouse and man 63\% (Fig. 1). The conserved regions were identified by comparison with the corresponding regions in other species: the first and second zinc fingers corresponding to the DNA binding domain (residues 13-78), the Ad4 BP/SF-1 box (residues 79-106), region II (residues 274-315), region III (residues 364-387) and the AF-2 domain (residues 458-463). The identity rate of each functional domain in SF-1 was also examined. In contrast to the second zinc finger, the first one is highly conserved between species, except for $P$. waltl, which exhibits a single 15-valine-toalanine amino-acid substitution. Nevertheless, the Pbox ESCKG localized in the first zinc finger is conserved in our model. SF-1 box, region II and region III present also a high degree of identity among most species (75-100\%) while the AF-2 motif, essential for transcriptional activation, is entirely conserved. A proline stretch of 7-8 consecutive amino acids is present in the mammalian SF-1 but absent in chicken, turtle, frog and Pleurodeles.

\section{SF-1 is expressed during early gonadal development}

The SF-1 mRNA expression pattern in the urogenital system of Pleurodeles larvae during the TSP was examined. Qualitative RT-PCR analysis in GMI from $\mathrm{ZZ}^{20}, \mathrm{ZW}^{20}$ and $\mathrm{ZW}^{32}$ larvae selected at different stages of their development showed that SF-1 is expressed early in the three types of larvae: SF-1 mRNAs are detected since stage 42, and their expression is maintained thereafter in a sex-independent manner through the whole TSP that ends at stage 54 (Fig. 2). Thus, SF-1 expression occurs before gonadal differentiation, which can be assessed at stage 53 by histologic examination. Besides, temperature appeared to have no silencing effect on SF-1 during this period of development.

\section{Sex- and tissue-specificity of SF-1 expression during gonadal differentiation}

SF-1 mRNA expressions were then compared by semiquantitative RT-PCR analyses performed from total RNA isolated either from GMI at stages 54 and 55, or from isolated Gd and MI taken at various subsets of stage 55 during which metamorphosis proceeds, and at stage 56 at which animals are metamorphosed (Table 2). The results were compared with those obtained in brain, another important, steroid-producing organ.

At stage 54, no significant difference could be detected between GMI from ZW ${ }^{20}$ and $Z^{20}$ larvae. Then, SF-1 expression in GMI was higher in $Z^{2} W^{20}$ individuals with a $2 \cdot 14$-fold higher mRNA level at the beginning of stage 55. After this stage, the Gd was big enough to allow their dissection and their study independently of MI. We observed the expression of SF-1 to be higher in the ovary at stages $55^{15 \mathrm{~d}}(1 \cdot 55$-fold $)$ and $55^{30 \mathrm{~d}}(1 \cdot 19$-fold $)$. This female-enriched expression was transient, since, at stage 56, there was no significant difference between $\mathrm{ZW}^{20}$ and $\mathrm{ZZ}^{20}$ animals. Surprisingly, a high SF-1 expression was observed in female MI at stage $55^{30 \mathrm{~d}}$ $(2 \cdot 15$-fold $)$, whereas no significant difference was found at stages $55^{15 \mathrm{~d}}$ and 56 . In the brain of $\mathrm{ZW}^{20}$ larvae, SF-1 mRNA level observed inside and outside TSP, that is, at stages 54 and $55^{15 \mathrm{~d}}$ respectively, was not significantly different from those in $Z^{20}$ ones.

\section{Tissue-specific inhibition of SF-1 expression after long-term heat treatment}

In order to test whether SF-1 mRNA expression is regulated by temperature, the SF-1 mRNA level in $\mathrm{ZW}^{32}$ larvae was compared with those measured in $\mathrm{ZW}^{20}$ ones in Gd, MI, GMI and brain as before. 
P. waltl

T. scripta

R. rugosa

chicken

mouse

human

P. waltI

T. scripta

$R$. rugosa

chicken

mouse

human

P. waltl

T. scripta

R. rugosa

chicken

mouse

human

P. waltl

T. scripta

R. rugosa

chicken

mouse

human

P. waltl

T. scripta

$R$. rugosa

chicken

mouse

human

P. waltl

T. scripta

$R$. rugosa

chicken

mouse

human

P. waltl

T. scripta

R. rugosa

chicken

mouse

human

P. waltl

T. scripta

R. rugosa

chicken

mouse

human
MEYTYDEDLDEI

MDYSYDEDPNQL

MDYSYDEDLDEL

MDYSYDEDLDEL

MDYSYDEDLDEL

MDYSYDEDLDEL

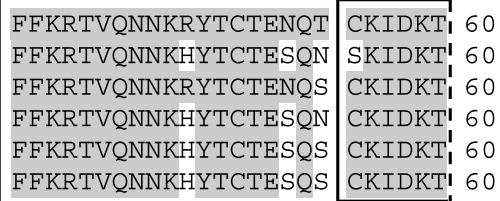

Zinc finger II

QRKRCPYCRFQKCLTVGM RLEAVRADRMRAGSNKFGPMYKRDRALK

I QRKRCPYCRFQKCLTVGM RLEAVRADRMRGGRNKFGPMYKRDRALK

QRKRCPYCRFQKCLNVGM RLEAVRADRMRGGRNKFGPMYKRDRALK

I QRKCCPYCRFQKCLTVGM RLEAVRADRMRGGRNKFGPMYKRDRALK

QRKRCPFCRFQKCLTVGM RLEAVRADRMRGGRNKFGPMYKRDRALK

I QRNRCPFCRFQKCLTVGM

\section{Zinc finger II} RLEAVRADRMRGGRNKFGPMYKRDRALK

\section{Ad4BP/SF-1 box}

ETVPQIVSPTQTEYTIPSNIHSIHSVSKSLPLNTVAMTQVNYDRSPYGTPSLGMTMP -NH 179 ETVPQIVSPVQTDYNLSSTIHGIHSVSKSLPPNPATMTPVDYDRSPYGTPSLGMTVP-SH 179 ETVPQIVSQVQTDYSVANNIHTIHPVSKNLPSNTAPMTPVEYDRGSYGPPPIAMTLP-NH 179 ETVPQIVSPVQNDYGLSSTIHS IHAMAKTLPPNPAALTPADYERGPYGTPSLAMTVP-GH 179 ETGPPMGVPPPPPPPPD - - YMLPPSLHAPEPKALVSGPPSGPLGDFGAPSLPMAVPGPH 177 ETGPPMGVPPPPPPAPD - - YVLPPSLHGPEPKGLAAGP PAGPLGDFGAPALPMAVPGAH 177

GALQGYTYPHFPNRTIKSEFPDHYSSPHES-VAPAFVYSDAYQNSFPPDIPETILNLLQL 238 GALSSYHYPSFPNRTIKSEYPDHYTNSHES - VASYMYPDAYPNSAPPDIPEVILKLLQL 237 APLSGYHYSSFQSRTIKSEYPDHYSNVHDPSTAGGYVYPEAYTSTSQPDIPEVILKLLQL 239 TPLAGYHYPSFPNRAIKSEYPDHYSAAHEA--VPTYAYPETYPSSSPPDIPEVILKLLQL 237 GPLAGYLYPAFSNRTIKSEYPEPYASPPQQ- - PGPPYSYPEPFSGGPNVPELILQLLQL 234 GPLAGYLYPAFPGRAIKSEYPEPYASPPQ--- -PGLPYGYPEPFSGGPNVPELILQLLQL 233

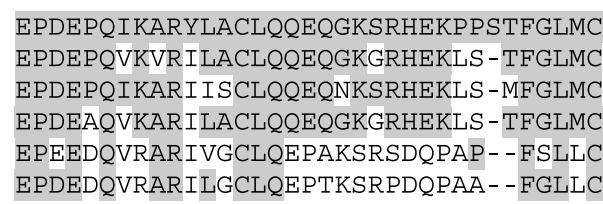
EPDEDQVRARILGCLQEPTKSRPDQPAA - FGLLC

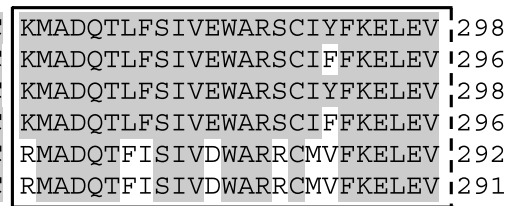

\section{Region II}

DHIYRQIQHGKENSILLVTGQEIDVSTIAAQAGPALNNLVLKS 358 DHIYRQVQHGKEHSMLLVTGQEVEMATIAAQAGSNLNNLVLRA 356 DHIYRQMQHSKENSILLVTGQEIELSAIAAQAGSTLNNLVLRA 358 DHVYRQLQHGKEHSVLLVTGQEVDLSAVAAQAGS ILHSLVLRA 356 DHIYRQVQYGKEDSILLVTGQEVELSTVAVQAGSLLHSLVLRA 352 DHIYRQVQHGKEGSILLVTGQEVELTTVATQAGSLLHSLVLRA 351 \begin{tabular}{l} 
GDQMILLQNCWSELLVF \\
GDQMKLLQNCWSELLVF \\
SDQMILLQNCWSELLVF \\
GDQMKLLQNCWSELLVF \\
ADQMTLLQNCWSELLVL \\
\hline
\end{tabular}

\begin{tabular}{l} 
GDQMILLQNCWSELLVF \\
GDQMKLLQNCWSELLVF \\
SDQMILLQNCWSELLVF \\
GDQMKLLQNCWSELLVF \\
ADQMTLLQNCWSELLVL \\
\hline
\end{tabular}

\begin{tabular}{l|l|}
\cline { 2 - 3 } QELVI & QLHSLQVDRQEFVCLKFLILFSVD \\
QELVL & HLHSLQVDRQEFVCLKFLILFSLD \\
QELVI & LLHSLQVDRQEFVCLKFLILFSLD \\
QELVL & HLHSPQVDRQEFVCLKFLILFSLD \\
QELVL & QLHALQLDRQEFVCLKFLILFSLD \\
QELVL & QLLALQLDRQEFVCLKFI ILFSLD \\
\hline
\end{tabular}

\section{Region III}

CMDKFRLLLLRLTDIRS ISMLAEDYLYHKHMSGEVPCNN AADKFRQLLLRLAEIRSLSMQAEEYLYHKHLSGEVPCNN CTDKYRLLLLRLAEIRS ISMQAEEYLYHKHLSGEVPCNN CTDKFRQLLLRLTEVRALSMQAEEYLYHKHLSGEVPCNN CGDKFQQLLLCLVEVRALSMQAKEYLYHKHLGNEMPRNN CGDKFQQLLLCLVEVRALSMQAKEYLYHKHLGNEMPRNN
EKCLENNTLARNAQEKINAALHEYTMCHYPH 418 VKYLENHSLAKDAQEKANAALLEYTICHYPH 416 EKFLENHSLAKSAQEKVDSALMEYTMCHYPH 418 VKYLENHALAKDAQEKANAALLEYTVCHYPH 416 VKFLNNHSLVKDAQEKANAALLDYTLCHYPH 412 LKFLNNHILVKDAQEKANAALLDYTLCHYPH 411

- AF-2

\begin{tabular}{|l|llrl}
\hline LLIEML & HAKRS & 468 & $100 \%$ & identity \\
LLIEML & HAKRT & 466 & $81 \%$ & identity \\
LLIEML & HAKRA & 468 & $79 \%$ & identity \\
LLIEML & HAKRT & 466 & $78 \%$ & identity \\
LLIEML & QAKQT & 462 & $63 \%$ & identity \\
LLIEML & QAKQT & 461 & $63 \%$ & identity
\end{tabular}

AF-2

Figure 1 Alignment of the amino-acid sequences of SF-1 cDNAs from several vertebrate species. Amino-acid identity with Pleurodeles sequence is shown in gray. The conserved regions, zinc finger I, zinc finger II, Ad4BP (Ad4 binding protein)/SF-1 box, region II, region III and AF-2, are framed. The mammalian proline stretch is in boldface. 


\section{Developmental stages}

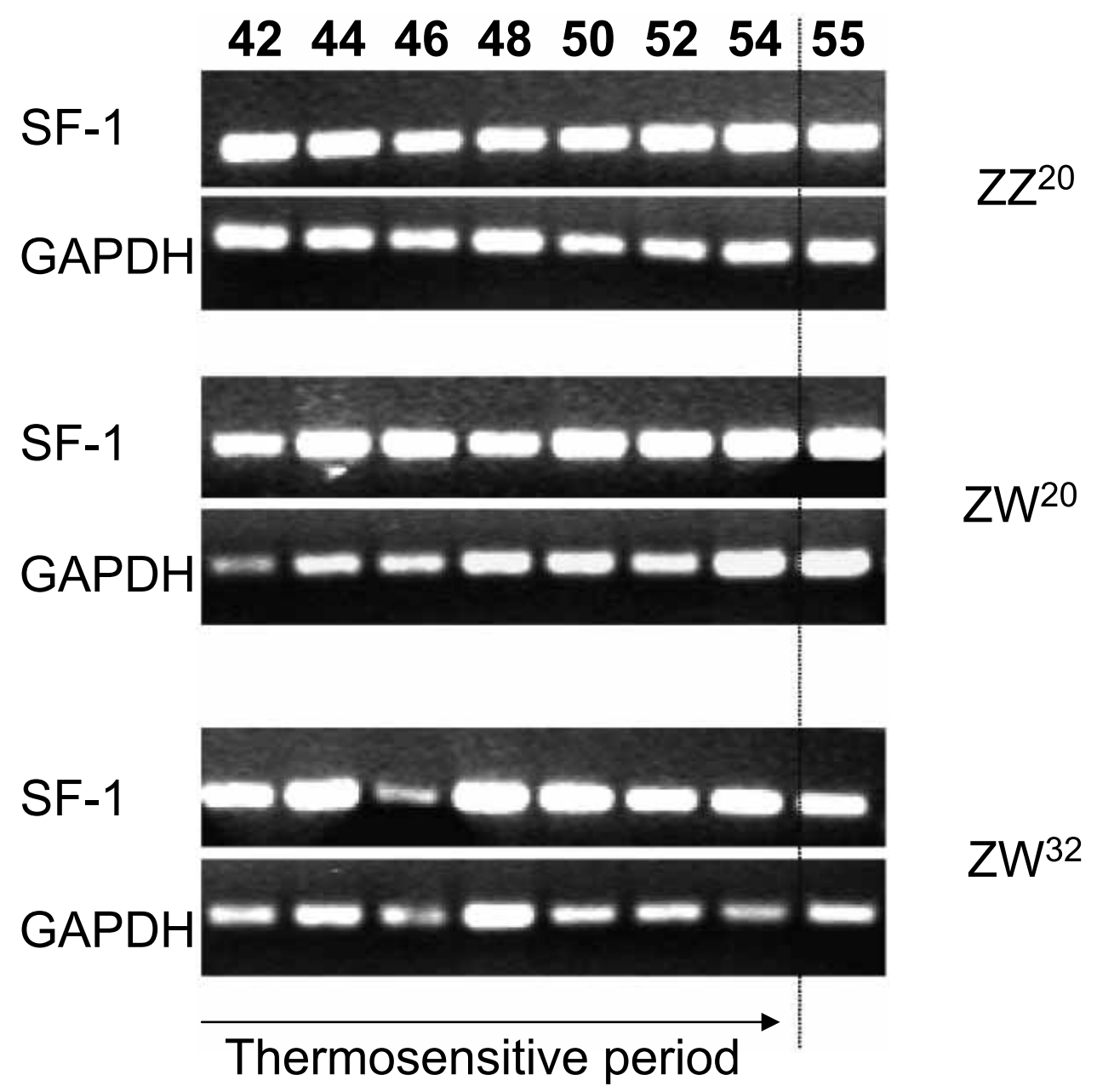

Figure 2 Analysis of SF-1 mRNA expression in Pleurodeles gonad-mesonephros-interrenal complex (GMI). $Z Z$ and $Z W$ larvae raised at $20^{\circ} \mathrm{C}\left(Z^{20}\right.$ and $\left.Z W^{20}\right)$ and $Z W$ larvae exposed at a temperature of $32{ }^{\circ} \mathrm{C}\left(Z W^{32}\right)$ were sampled at various stages of TSP $(42-54)$ and at stage 55. Total RNA was extracted from a pool of GMI dissected from five larvae, reverse transcribed and amplified by PCR for 35 cycles. GAPDH mRNA level is used as a control.

At stage 54, no difference in SF-1 mRNA level was detected in GMI between $\mathrm{ZW}^{32}$ and $\mathrm{ZW}^{20}$ larvae, whereas at stage $55^{15 \mathrm{~d}}$, a reduced expression $(1 \cdot 6$-fold $)$ was observed (Table 3). In Gd of larvae at the same stage $\left(55^{15 \mathrm{~d}}\right)$, a higher difference was observed between heat-treated larvae and controls, heat treatment leading to a $3 \cdot 7$-fold lower expression of SF-1. The inhibitory effect of heat treatment on gonadal SF-1 expression was confirmed at stage $55^{30 \mathrm{~d}}(2 \cdot 2$-fold lower SF-1 mRNA level). Interestingly, at this stage, a similar situation was observed in MI: there was a $3 \cdot 4$-fold lower expression of SF-1 in this organ in $\mathrm{ZW}^{32}$ larvae. Therefore, heat treatment performed from stage 42 to 54 affects SF-1 expression not only in Gd but also in MI. Besides, this effect appears late, after the end of the TSP. In the brain, SF-1 transcription is not temperature-sensitive either during the TSP (stage 54) or after the end of TSP (stage $55^{15 \mathrm{~d}}$ ).

\section{Gonadal SF-1 expression is not inhibited by $48-\mathrm{h}$} heat shock

The inhibition of SF-1 expression described above is observed after sex-reversing heat treatment is completed, suggesting that temperature does not act directly on SF-1 expression. In order to get more information about the relationship between temperature and SF-1 expression, a $48-\mathrm{h} 32{ }^{\circ} \mathrm{C}$ heat shock was applied to ZW larvae 
Table 2 ZW20/ZZ20 SF-1 mRNA expression ratio in gonad and/or mesonephros-interrenal and brain

SF-1 expression in ZW20/SF-1 expression in $Z^{20}(1)$

\begin{tabular}{|c|c|c|c|c|}
\hline & & & & \\
\hline & GMI(3) & Gonad & Mesonephros-interrenal & Brain \\
\hline $\begin{array}{l}\text { Stage of } \\
\text { larval development }{ }^{(2)}\end{array}$ & & & & \\
\hline Stage 54 & $\begin{array}{l}0 \cdot 78^{(4)} \\
P=0 \cdot 434^{(6)} \\
n\left(Z W^{20}\right)=5 ; n\left(Z Z^{20}\right)=6\end{array}$ & $N D^{(5)}$ & ND & $\begin{array}{l}0.95 \\
P=0.671 \\
n\left(Z W^{20}\right)=5 ; n\left(Z Z^{20}\right)=6\end{array}$ \\
\hline Stage 55 & $\begin{array}{l}2.14 \\
P=0 \cdot 001 \\
n\left(Z W^{20}\right)=6 ; n\left(Z Z^{20}\right)=5\end{array}$ & ND & ND & ND \\
\hline Stage $55^{15 d}$ & ND & $\begin{array}{l}1.55 \\
P=0.021 \\
n\left(Z W^{20}\right)=4 ; n\left(Z Z^{20}\right)=5\end{array}$ & $\begin{array}{l}1 \cdot 29 \\
P=0 \cdot 123 \\
n\left(Z W^{20}\right)=4 ; n\left(Z Z^{20}\right)=5\end{array}$ & $\begin{array}{l}0.91 \\
P=0.515 \\
n\left(Z W^{20}\right)=4 ; n\left(Z Z^{20}\right)=4\end{array}$ \\
\hline Stage $55^{30 d}$ & ND & $\begin{array}{l}1.19 \\
P=0.022 \\
n\left(Z W^{20}\right)=4 ; n\left(Z Z^{20}\right)=4\end{array}$ & $\begin{array}{l}2 \cdot 15 \\
P=0 \cdot 003 \\
n\left(Z W^{20}\right)=4 ; n\left(Z Z^{20}\right)=4\end{array}$ & ND \\
\hline Stage 56 & ND & $\begin{array}{l}0.98 \\
P=0.956 \\
n\left(Z W^{20}\right)=6 ; n\left(Z Z^{20}\right)=6\end{array}$ & $\begin{array}{l}1.03 \\
P=0.890 \\
n\left(Z W^{20}\right)=4 ; n\left(Z Z^{20}\right)=4\end{array}$ & ND \\
\hline
\end{tabular}

(1) SF-1 mRNA/GAPDH mRNA expression ratio measured in ZW20 larvae and divided by those measured in $\mathrm{ZZ}^{20}$ larvae. (2) More details about developmental stages are in Materials and methods. (3) Gonad and mesonephros-interrenal attached (see Materials and methods). (4) Significant values $(P \leq 0.05)$ are in bold face. (5) Not determined. (6) The mean of relative SF-1 mRNA level from each group, $n\left(Z W^{20}\right)$ and $n\left(Z Z^{20}\right)$, was compared (Student's $t$-test).

(ZW $\left.{ }^{\text {hs }}\right)$; then, aromatase and SF-1 mRNA levels were measured and compared with those in $Z^{20}$ larvae in GMI at stage 55 and in Gd or MI at stage $55^{30 d}$ (Fig. 3). As previously described (Kuntz et al. 2003b), aromatase was absent from MI (not shown), and its expression in Gd was insensitive to heat shock when applied after the TSP (Fig. 3A). Conversely, SF-1 mRNA level (Fig. 3B) is slightly reduced under heat shock in GMI at early stage $55(1 \cdot 2$-fold; $P=0 \cdot 355)$ and in $\mathrm{MI}$ at stage $55^{30 \mathrm{~d}}$ $(1 \cdot 34$-fold; $P=0 \cdot 127)$, but not in the isolated $\mathrm{Gd}$ at stage $55^{30 \mathrm{~d}}$, wherein it appears to be significantly upregulated $(1 \cdot 18$-fold; $P=0 \cdot 026)$. This result suggests that Pleurodeles
SF-1 is not directly downregulated by temperature. Rather, raising temperature can increase SF-1 mRNA level, at least at stage $55^{30 \mathrm{~d}}$, by an unknown tissue-dependent mechanism.

\section{Estrogen sensitivity of SF-1 expression after the end of the TSP}

The female-enriched expression of SF-1 occurs after the female-specific increase in aromatase expression. Besides, a decreased SF-1 expression is observed after long-term heat treatment, which is known to

Table 3 ZW²/ZW20 SF-1 mRNA expression ratio in gonad and/or mesonephros-interrenal and brain

SF-1 expression in ZW32/SF-1 expression in ZW20 (1)

\begin{tabular}{|c|c|c|c|c|}
\hline & $\mathrm{GMI}^{(3)}$ & Gonad & Mesonephros-interrenal & Brain \\
\hline Stage $55^{15 d}$ & $\begin{array}{l}0.61 \\
P=0.008 \\
n\left(\mathrm{ZW}^{32}\right)=4 ; n\left(\mathrm{ZW}^{20}\right)=5\end{array}$ & $\begin{array}{l}\mathbf{0 . 2 7} \\
P=0 \cdot 001 \\
n\left(Z \mathrm{~W}^{32}\right)=3 ; n\left(Z \mathrm{~W}^{20}\right)=4\end{array}$ & ND & $\begin{array}{l}1.08 \\
P>0.999 \\
n\left(Z W^{32}\right)=4 ; n\left(Z W^{20}\right)=4\end{array}$ \\
\hline
\end{tabular}

(1) SF-1 mRNA/GAPDH mRNA expression ratio measured in ZW 32 larvae and divided by those measured in ZW20 larvae. (2) More details about developmental stages are in Materials and methods. (3) Gonad and mesonephros-interrenal attached (see Materials and methods). (4) Significant values are in bold face. (5) Not determined. (6) The mean of relative SF-1 mRNA level from each group, $n\left(Z W^{32}\right)$ and $n\left(Z W^{20}\right)$, was compared (ANOVA followed by Bonferroni test). 
(A)
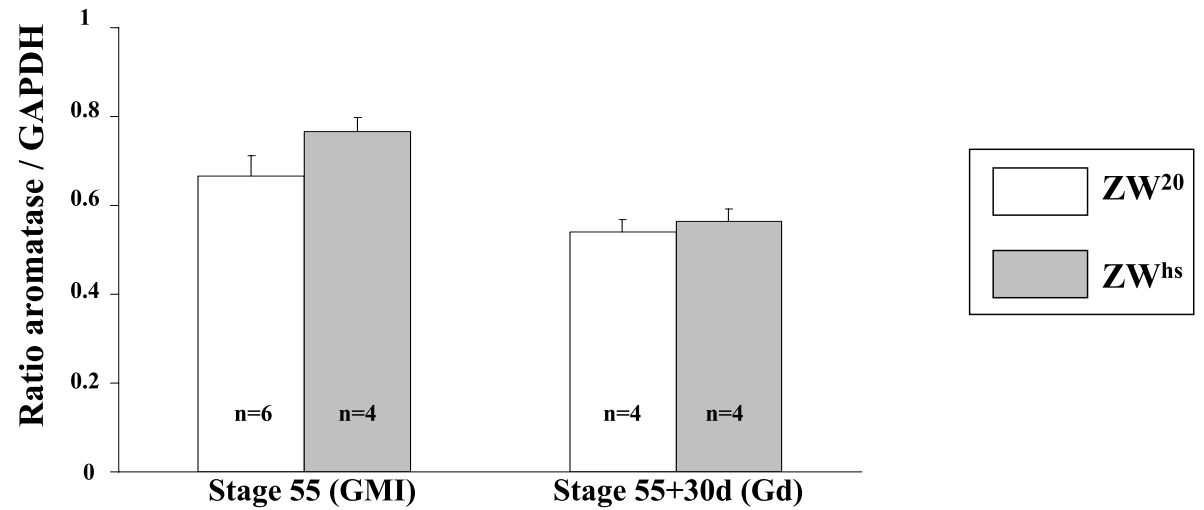

(B)

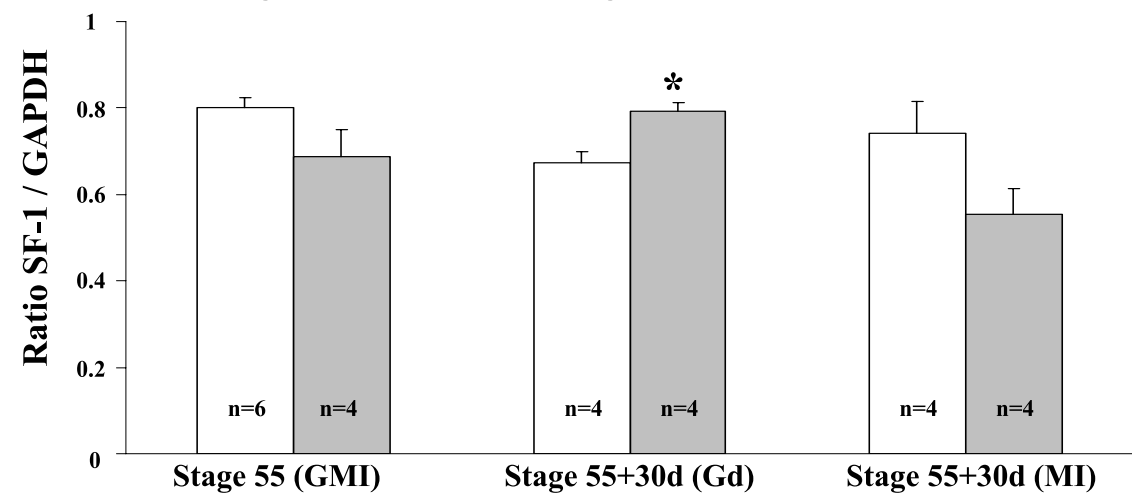

Figure 3 Heat-shock analysis of SF-1 and aromatase mRNA level in gonad (Gd), mesonephros-interrenal (MI) and gonad-mesonephros-interrenal complex (GMI). Expression during early sexual differentiation (stages 55 and $55^{30 d}$ ) was measured in $Z W^{20}$ and compared with those in ZW larvae submitted to a $48-\mathrm{h} 32{ }^{\circ} \mathrm{C}$ heat shock $(\mathrm{ZWh})$. Total RNA from a pool of four or five larvae was reversed transcribed and amplified by PCR for 28 cycles. PCR products were agarose gel fractionated, and relative amounts of aromatase (A) and SF-1 (B) mRNAs were normalized to GAPDH mRNA level. Values are means of four or six replicates: the number of pools is indicated by ' $n$ '. Vertical bars indicate the mean standard error. To calculate the $P$ value, the mean of relative SF-1 mRNA level from each group, $n\left(Z W^{\text {hs }}\right)$ and $n\left(Z W^{20}\right)$, was compared (ANOVA followed by the Bonferroni test). ${ }^{*} P<0.05$ vs $Z W^{20}$.

downregulate aromatase expression in ZW larvae. These results strongly suggest a relationship between estrogens and SF-1 expression in Pleurodeles. To test this hypothesis, we performed 48-h estrogen treatments of $\mathrm{ZZ}$ larvae $\left(\mathrm{ZZ}{ }^{\mathrm{E} 2}\right)$. The mRNA expression of both aromatase and SF-1 was compared with those in $Z^{2} W^{20}$ and $Z^{20}$ larvae in GMI at stage 55 and in Gd or MI at stage $55^{30 \mathrm{~d}}$ (Fig. 4). We confirmed our previous studies showing the absence of aromatase expression in MI (Kuntz et al. 2003b). In Gd, we observed aromatase mRNA expression to be increased in $Z^{\mathrm{E} 2}$ versus $\mathrm{ZZ}^{20}$ larvae $(2 \cdot 1$-fold; $P=0 \cdot 003)$ when estradiol benzoate was applied at stage 55 (Fig. 4A). Such a sensitivity was not observed when the hormonal treatment was performed at stage $55^{30 \mathrm{~d}}$. As observed for aromatase, SF-1 mRNA expression is upregulated in GMI $(2 \cdot 4$-fold; $P=0 \cdot 002)$ when estradiol benzoate was applied at stage 55 (Fig. 4B). When the treatment was performed at stage $55^{30 \mathrm{~d}}$, such an increase was not observed in $\mathrm{Gd}$, while a significant difference was still observed in MI between $Z^{20}$ and $Z^{\mathrm{E} 2}$ larvae (1.8-fold; $P=0 \cdot 008$ ). Moreover, in all cases shown in Fig. 4 , the SF-1 mRNA level in $Z Z^{\mathrm{E} 2}$ larvae was not significantly different from that in $\mathrm{ZW}^{20}$ ones. Taken together, these results suggest that mesonephric and/or interrenal SF-1 expression can be increased by circulating estrogens after gonadal differentiation, that is, after the ovarian raise in the level of aromatase expression and activity.

\section{Discussion}

Little is known about SF-1 in amphibians, and its involvement in the regulation of steroid hormone synthesis has still to be demonstrated in $P$. waltl. Whether SF-1 is involved in the transcriptional regulation of aromatase in $P$. waltl is one of the questions we address here. This work was also performed in order to 


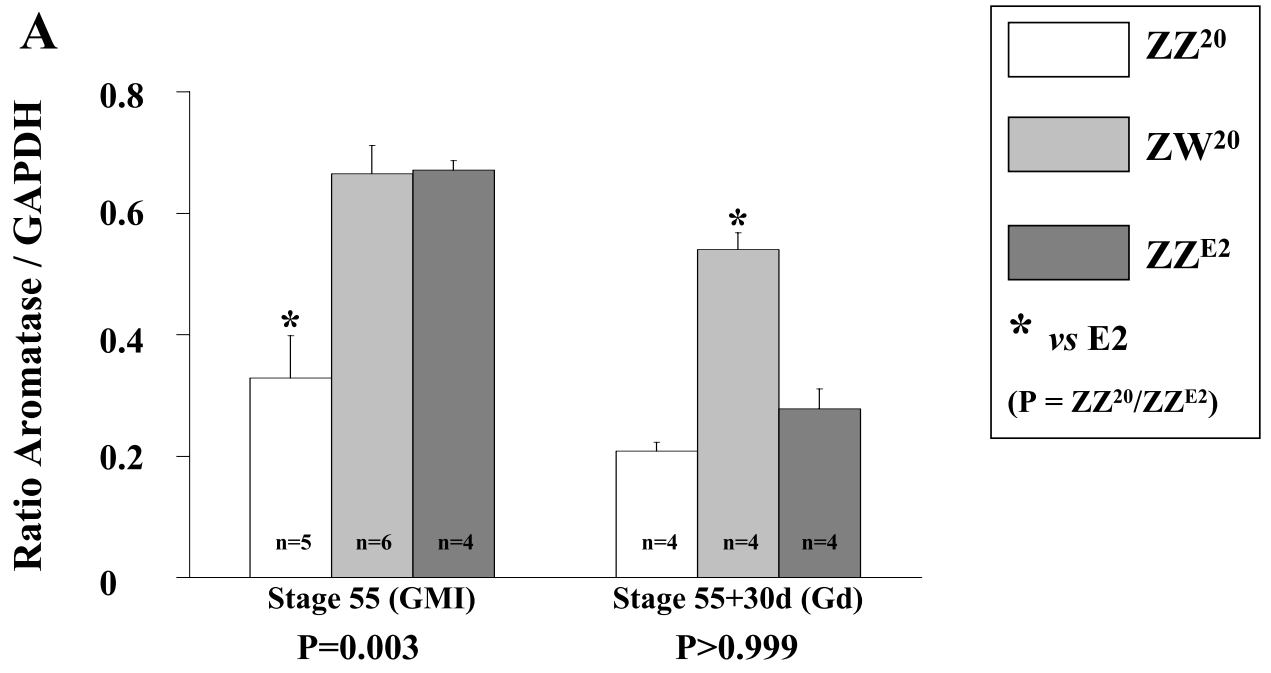

B

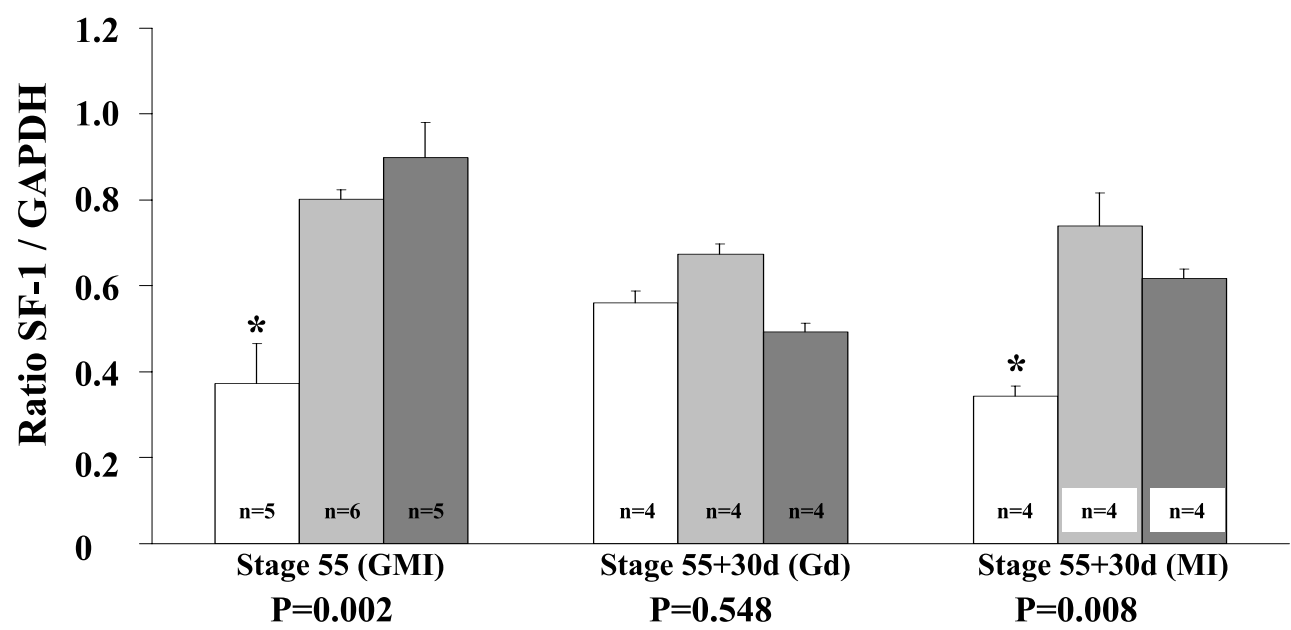

Figure 4 Effect of estradiol benzoate on aromatase and SF-1 mRNA level in gonad (Gd), mesonephros-interrenal (MI) and gonad-mesonephros-interrenal complex (GMI). Total RNA was extracted from ZZ larvae reared in $100 \mu \mathrm{g} / \mathrm{l}$ estradiol benzoate for $48 \mathrm{~h}\left(\mathrm{ZZ}{ }^{\mathrm{E} 2}\right.$ ) at stages 55 and $55^{30 \mathrm{~d}}$. (A) As a control, aromatase mRNA expression, absent in MI, is shown in GMI and Gd. (B) RT-PCR analysis of SF-1 expression was examined in the conditions described in Fig. 3. Amounts of SF-1 and aromatase mRNAs were normalized to GAPDH mRNA level, and values were analyzed as described in Fig. 3 by comparing the mean of relative mRNA level of the two groups: $n\left(Z Z^{20}\right)$ and $n\left(Z Z Z^{\mathrm{E}}\right)$.

determine whether SF-1 could itself constitute an upstream target of the masculinizing temperature which leads to downregulation of aromatase expression (Kuntz et al. 2003b).

We first cloned from adult testis Pleurodeles SF-1 cDNA containing an open reading frame that could encode a protein of 468 amino acids. Sequence identity of the deduced protein compared with polypeptides found in other vertebrates showed a high homology, ranging from $81 \%$ in T. scripta to $63 \%$ in man and mouse. As expected, the regions that correspond to known functional domains in the nuclear receptor family showed higher amino-acid identity than for the protein as a whole. These results suggest that biologic SF-1 function can be conserved in Pleurodeles species.

SF-1 was described as a transcription factor expressed in several tissues involved in reproduction and/or steroidogenesis and is currently detected in brain, testis, ovary, and interrenal or adrenal tissue in mouse, chicken, T. scripta and frog (Ingraham et al. 1994, Kawano et al. 1998, Fleming et al. 1999, Smith et al. 1999, Mayer et al. 2002). As in other species, Pleurodeles SF-1 transcripts were detected in all adult steroidogenic tissues (Kuntz et al. 2004a) as well as in spleen, as 
observed in $R$. rugosa (Kawano et al. 1998), and, surprisingly, in lung, where aromatase activity is also present (Kuntz et al. 2004a). These results suggest a role for SF-1 in the steroid hormone synthesis pathway, as in chicken (Kudo et al. 1996), and Xenopus (Akatsuka et al. 2005) and teleost (Gardner et al. 2005) species, where SF-1 consensus binding sites are conserved in aromatase 5 '-flanking region. However, Pleurodeles SF-1 cis-acting targets in the aromatase gene promoter remain to be discovered.

Then we examined $P$. walt $\mathrm{SF}-1$ expression during sexual differentiation. Qualitative expression analysis revealed the presence of an SF-1 transcriptional activity as early as stage 42 , in $Z^{20}$ and $Z^{20}$ or $Z^{2} W^{32}$, and this sex- and temperature-independent signal was observed at all stages of the TSP. This result is consistent with those obtained in mouse, where SF-1 transcripts are present in the undifferentiated urogenital ridge in both sexes before the onset of Sry expression (Ikeda et al. 1993). Such a gonadal expression pattern, prior to sexual differentiation, is also observed in chicken (Smith et al. 1999), turtle (T. scripta) (Fleming et al. 1999), alligator (Western et al. 2000) and frog (R. catesbeiana) (Mayer et al. 2002). This early presence of SF-1 mRNA in Pleurodeles GMI is correlated with its role in the first differentiation steps of the two primary steroidogenic organs: the $\mathrm{Gd}$ and interrenal tissue, as demonstrated in other species (Luo et al. 1994). Furthermore, gonadal SF-1 expression occurs before expression of its steroidogenic target genes (Parker \& Schimmer 2002). However, the question of whether SF-1 is expressed during the TSP in Gd, MI or both in $P$. waltl awaits an answer from in situ hybridization studies. Such histologic investigations would also determine whether SF-1 expression and activity are localized in aromatase-producing cells.

After the onset of gonadal sex differentiation, the SF-1 expression pattern becomes sexually dimorphic among species. In mouse embryos, SF-1 expression persists during testicular differentiation, but it declines during ovarian differentiation (Ikeda et al. 1994). A similar pattern was found in other mammals (Hatano et al. 1994, Pilon et al. 1998, Hanley et al. 2000) and in turtle (T. scripta) (Fleming et al. 1999), but not in chicken (Smith et al. 1999), alligator (Western et al. 2000), frog ( $R$. catesbeiana) (Mayer et al. 2002) or $P$. waltl. In the last mentioned, our semiquantitative analysis showed a transient increase of the SF-1 transcript level in the ovary after the beginning of its differentiation. This sexually dimorphic expression was detected at stages $55^{15 \mathrm{~d}}$ and $55^{30 \mathrm{~d}}$, which develop after the first evidence of histologic sex differentiation that takes place at stage 53 . The female-enriched expression was higher at stage $55^{15 \mathrm{~d}}$ than at stage $55^{30 \mathrm{~d}}$, whereas no significant difference was observed at stage 56 . The ovarian specific increase in SF-1 expression could appear as early as stage 55, since a 2.14-fold higher expression was detected in GMI at this stage. However, since at this stage as well as earlier ones, we could not separate Gd from MI, and since both tissues express SF-1, this hypothesis cannot be validated. Surprisingly, in MI, a similar transient increase in SF-1 expression in $\mathrm{ZW}^{20}$ larvae was observed, but it appeared at stage $55^{30 \mathrm{~d}}$, that is, later than in $\mathrm{Gd}$. The delay observed for the maximum SF-1 expression in MI suggests that the SF-1 gene may be more directly activated in $\mathrm{Gd}$, where aromatase is expressed, than in MI, where aromatase is not transcribed. We note that expression of SF-1 in mesonephros or interrenal tissue is very poorly described in the literature; to our knowledge, there are no data about it during the period of sex differentiation. It appears that SF-1 gene transcription can be positively regulated by estrogen in Pleurodeles. Indeed, we observed that upregulation of SF-1 mRNA expression can be triggered by exogenous stimulation with estradiol benzoate. In $\mathrm{Gd}$, the local production of these hormones can stimulate SF-1 expression earlier than in MI, which does not produce estrogen and is sensitive to the sole circulating hormones. In T. scripta, estrogen was also shown to modulate the regulation of SF-1 transcription, since treatment with estradiol applied at a maleproducing temperature resulted in upregulation of gonadal SF-1 and female hatching (Fleming \& Crews 2001). However, whether estrogens have a direct or indirect effect on SF-1 expression is not known. Therefore, in $P$. waltl, SF-1 expression could be correlated with the high level of steroidogenic activity necessary to support female sexual development, as in chicken embryos, where the developing ovary displays a higher steroidogenic activity than the testis (Woods \& Erton 1978, Guichard et al. 1979), while the opposite is observed in mammals (Jost 1970). In Pleurodeles, the aromatase and SF-1 expression patterns appear to be closely related, both increasing, during ovarian differentiation, respectively at stages 54 (Kuntz et al. 2003b) and 55 (this work). However, SF-1 expression decrease at stage 56 cannot be explained by a reduction in aromatase activity, which is still high at this moment (Chardard \& Dournon 1999). Instead, this decrease may be related to the end of the hormone-sensitive period, at which aromatase expression is no longer activated by estradiol.

Whether the SF-1 gene, as a possible regulator of aromatase, is a target of temperature in Pleurodeles temperature-dependent sex reversal is another question we address. Our results obtained under heat treatment differ from those obtained in T. scripta, in which SF-1 mRNAs increase at male-producing temperature but decline at female-producing temperature (Fleming et al. 1999), but are closer to those obtained in $R$. rugosa, in which SF-1 mRNA level remains unchanged in the female-to-male sex reversal, while that of $\mathrm{P} 450$ aromatase declines (Kato et al. 2004). Indeed, in our 
model, we detected a significant decrease in SF-1 expression in $\mathrm{Gd}$ of $\mathrm{ZW}^{32}$ larvae at stages $55^{15 \mathrm{~d}}$ and $55^{30 \mathrm{~d}}$ with regard to that observed in $\mathrm{ZW}^{20}$ ones. Such a significant decrease is also observed in $\mathrm{MI}$ at stage $55^{30 \mathrm{~d}}$. According to the results of estrogen treatments, this inhibition of the female-specific peak of SF-1 mRNA in both Gd and MI could be due to the previously described defect in aromatase expression and estrogen synthesis induced under the effect of heat treatment leading to sex reversal (Chardard et al. 1995). These results support the hypothesis of a regulation of SF-1 gene expression by estrogen level rather than by a direct effect of temperature. This is strengthened by the fact that, when larvae are submitted to a 48-h heat shock, the SF-1 mRNA response is quite different from that observed after long-term heat treatment, since a weak but not significant inhibition of SF-1 transcription can be observed in MI, while mRNA level is significantly increased in Gd. Since this test was run after TSP, this does not mean that SF-1 could be a target of the masculinizing temperature in the course of sex reversal.

Recently, the brain has been suggested to be involved in sex determination in a turtle exhibiting temperature sex determination (TSD), such as Malaclemys terrapin, in which temperature-dependent SF-1 mRNA level rises earlier in female than in male brain before gonadal differentiation (Jeyasuria \& Place 1997). In T. scripta, the brain also seems to be the site of aromatase response to temperature, since differential aromatase activity was detected in brain during the TSP, whereas no differential activity was observed in Gd (Willingham et al. 2000, Crews et al. 2001). In Pleurodeles, our semiquantitative RT-PCR analysis did not show any differential expression of SF-1 in brain from $Z^{20}, Z^{20}$ and $Z^{20}{ }^{32}$ larvae taken at the beginning of sex-specific gonadal differentiation. This result is similar to that observed for aromatase expression (Kuntz et al. 2004b), suggesting that brain does not significantly interfere in the sexual determination or differentiation of the Gd in $P$. waltl and would not be considered to play a role in temperaturedependent sex reversal.

This work sheds a new light on the agents involved in Pleurodeles gonadal differentiation, although aromatase and estrogen seem to remain, at that time, the most important pieces of the puzzle. However, additional results will be necessary to understand the overall regulation of estrogen synthesis and the actual involvement of SF-1 in the complex path of ovarian differentiation and/or determination.

\section{Acknowledgements}

We thank Jean-Charles Olry and Alain Iurétig for animal rearing, and Henri Schroeder for valuable help in statistical analysis of results. The authors declare that there is no conflict of interest that would prejudice the impartiality of this scientific work.

\section{Funding}

This work was supported by grants from the Ligue Contre le Cancer, comités de la Meurthe et Moselle, de la Meuse et des Vosges, the Association pour la Recherche sur le Cancer, the Université Henri Poincaré-Nancy 1 (BQR), and the Conseil Régional de Lorraine. S K is a recipient of a grant from the French Ministère de l'Education Nationale, de l'Enseignement Supérieur et de la Recherche.

\section{References}

Achermann JC, Ito M, Ito M, Hindmarsh PC \& Jameson JL 1999 A mutation in the gene encoding steroidogenic factor-1 causes XY sex-reversal and adrenal failure in humans. Nature Genetics 22 125-126.

Akatsuka N, Komatsuzaki E, Ishikawa A, Suzuki I, Yamane N \& Miyata S 2005 Expression of the gonadal p450 aromatase gene of Xenopus and characterization of the $5^{\prime}$-flanking region of the aromatase gene. Fournal of Steroid Biochemistry and Molecular Biology 94 (Epub).

Chardard D \& Dournon C 1999 Sex-reversal by aromatase inhibitor treatment in the newt Pleurodeles waltl. Fournal of Experimental Zoology $28343-50$.

Chardard D, Desvages G, Pieau C \& Dournon C 1995 Aromatase activity in larval gonads of Pleurodeles waltl (Urodele Amphibia) during normal sex differentiation and during sex-reversal by thermal treatment effect. General and Comparative Endocrinology 99 $100-107$.

Crews D, Fleming A, Willingham E, Baldwin R \& Skipper JK 2001 Role of steroidogenic factor 1 and aromatase in temperature-dependent sex determination in the red-eared slider turtle. Fournal of Experimental Zoology 290 597-606.

Dournon C \& Houillon C 1984 Genetic demonstration of functional sex inversion in Pleurodeles waltii Michah (Urodele Amphibian) under the effect of temperature. Reproduction, Nutrition, Development 24 361-378.

Fleming A \& Crews D 2001 Estradiol and incubation temperature modulate regulation of steroidogenic factor 1 in the developing gonad of the red-eared slider turtle. Endocrinology 142 1403-1411.

Fleming A, Wibbels T, Skipper JK \& Crews D 1999 Developmental expression of steroidogenic factor 1 in a turtle with temperature-dependent sex determination. General and Comparative Endocrinology 116 336-346.

Gallien L 1951 Unisexual progeny of a female Pleurodeles Waltlii Michah, subjected, during the larval stage, to the gynogenic effect of estradiol benzoate. Comptes Rendus Hebdomadaires des Séances de l'Académie des Sciences 233 828-830.

Gallien L \& Durocher M 1957 Table chronologique du développement chez Pleurodeles waltl. Bulletin Biologique France et Belgique 91 97-114.

Gardner L, Andderson T, Place AR, Dixon B \& Elizur A 2005 Sex change strategy and the aromatase genes. Fournal of Steroid Biochemistry and Molecular Biology 94 395-404.

Guichard A, Cedard L, Mignot TM, Scheib D \& Haffen K 1979 Radioimmunoassay of steroids produced by chick embryo gonads cultured in the presence of some exogenous steroid precursors. General and Comparative Endocrinology 39 9-19. 
Hanley NA, Hagan DM, Clement-Jones M, Ball SG, Strachan T, Salas-Cortes L, McElreavey K, Lindsay S, Robson S, Bullen P, Ostrer H \& Wilson DI 2000 SRY, SOX9, and DAX1 expression patterns during human sex determination and gonadal development. Mechanisms of Development 91 403-407.

Hatano O, Takayama K, Imai T, Waterman MR, Takakusu A, Omura T \& Morohashi K 1994 Sex-dependent expression of a transcription factor, Ad4 BP, regulating steroidogenic P-450 genes in the gonads during prenatal and postnatal rat development. Development 120 2787-2797.

Ikeda Y, Lala DS, Luo X, Kim E, Moisan MP \& Parker KL 1993 Characterization of the mouse FTZ-F1 gene, which encodes a key regulator of steroid hydroxylase gene expression. Molecular Endocrinology 7 852-860.

Ikeda Y, Shen WH, Ingraham HA \& Parker KL 1994 Developmental expression of mouse steroidogenic factor-1, an essential regulator of the steroid hydroxylases. Molecular Endocrinology 8 654-662.

Ikeda Y, Luo X, Abbud R, Nilson JH \& Parker KL 1995 The nuclear receptor steroidogenic factor 1 is essential for the formation of the ventromedial hypothalamic nucleus. Molecular Endocrinology 9 478-486.

Ingraham HA, Lala DS, Ikeda Y, Luo X, Shen WH, Nachtigal MW, Abbud R, Nilson JH \& Parker KL 1994 The nuclear receptor steroidogenic factor 1 acts at multiple levels of the reproductive axis. Genes and Development 8 2302-2312.

Jeyasuria P \& Place AR 1997 Temperature-dependent aromatase expression in developing diamondback terrapin (Malaclemys terrapin) embryos. Fournal of Steroid Biochemistry and Molecular Biology $61415-425$

Jost A 1970 Hormonal factors in the sex differentiation of the mammalian foetus. Philosophical Transactions of the Royal Society of London. Series B, Biological Sciences 259 119-130.

Kato T, Matsui K, Takase M, Kobayashi M \& Nakamura M 2004 Expression of $\mathrm{P} 450$ aromatase protein in developing and in sex-reversed gonads of the XX/XY type of the frog Rana rugosa. General and Comparative Endocrinology 137 227-236.

Kawano K, Miura I, Morohashi K, Takase M \& Nakamura M 1998 Molecular cloning and expression of the SF-1/Ad4 BP gene in the frog, Rana rugosa. Gene 222 169-176.

Kudo T, Yamamoto H, Sato S \& Sutou S 1996 Comparison of 5' upstream regions of chicken and quail aromatase genes. Reproduction and Development 42 101-107.

Kuntz S, Chardard D, Chesnel A, Grillier-Vuissoz I \& Flament S $2003 a$ Steroids, aromatase and sex differentiation of the newt Pleurodeles waltl. Cytogenetics and Genome Research 101 283-288.

Kuntz S, Chesnel A, Duterque-Coquillaud M, Grillier-Vuissoz I, Callier M, Dournon C, Flament S \& Chardard D $2003 b$ Differential expression of $\mathrm{P} 450$ aromatase during gonadal sex differentiation and sex-reversal of the newt Pleurodeles waltl. Fournal of Steroid Biochemistry and Molecular Biology 84 89-100.

Kuntz S, Chardard D, Chesnel A, Ducatez M, Callier M \& Flament S 2004a Expression of aromatase and steroidogenic factor 1 in the lung of the urodele amphibian Pleurodeles waltl. Endocrinology 145 $3111-3114$

Kuntz S, Chesnel A, Flament S \& Chardard D $2004 b$ Cerebral and gonadal aromatase expressions are differently affected during sex differentiation of Pleurodeles waltl. Fournal of Molecular Endocrinology $33717-727$.

Lala DS, Rice DA \& Parker KL 1992 Steroidogenic factor I, a key regulator of steroidogenic enzyme expression, is the mouse homolog of fushi tarazu-factor I. Molecular Endocrinology 6 $1249-1258$

Luo X, Ikeda Y \& Parker KL 1994 A cell-specific nuclear receptor is essential for adrenal and gonadal development and sexual differentiation. Cell 77 481-490.

Lynch JP, Lala DS, Peluso JJ, Luo W, Parker KL \& White BA 1993 Steroidogenic factor 1 , an orphan nuclear receptor, regulates the expression of the rat aromatase gene in gonadal tissues. Molecular Endocrinology 7 776-786.

Mayer LP, Overstreet SL, Dyer CA \& Propper CR 2002 Sexually dimorphic expression of steroidogenic factor 1 (SF-1) in developing gonads of the American bullfrog, Rana catesbeiana. General and Comparative Endocrinology 127 40-47.

Michael MD, Kilgore MW, Morohashi K \& Simpson ER 1995 Ad4 BP/SF-1 regulates cyclic AMP-induced transcription from the proximal promoter (PII) of the human aromatase P450 (CYP19) gene in the ovary. Fournal of Biological Chemistry 270 13561-13566.

Parker KL \& Schimmer BP 2002 Genes essential for early events in gonadal development. Annals of Medicine 34 171-178.

Pilon N, Behdjani R, Daneau I, Lussier JG \& Silversides DW 1998 Porcine steroidogenic factor-1 gene (pSF-1) expression and analysis of embryonic pig gonads during sexual differentiation. Endocrinology 139 3803-3812.

Schnabel CA, Selleri L \& Cleary ML 2003 Pbxl is essential for adrenal development and urogenital differentiation. Genesis $\mathbf{3 7}$ $123-130$.

Shinoda K, Lei H, Yoshii H, Nomura M, Nagano M, Shiba H, Sasaki H, Osawa Y, Ninomiya Y \& Niwa O 1995 Developmental defects of the ventromedial hypothalamic nucleus and pituitary gonadotroph in the Ftz-F1 disrupted mice. Developmental Dynamics $20422-29$.

Smith CA, Smith MJ \& Sinclair AH 1999 Expression of chicken steroidogenic factor-1 during gonadal sex differentiation. General and Comparative Endocrinology 113 187-196.

Tanaka M, Fukada S, Matsuyama M \& Nagahama Y 1995 Structure and promoter analysis of the cytochrome P-450 aromatase gene of the teleost fish, medaka (Oryzias latipes). Fournal of Biochemistry (Tokyo) 117 719-725.

Tong SK \& Chung BC 2003 Analysis of zebrafish cyp19 promoters. Fournal of Steroid Biochemistry and Molecular Biology 86 381-386.

Val P, Lefrancois-Martinez AM, Veyssiere G \& Martinez A 2003 SF-1 a key player in the development and differentiation of steroidogenic tissues. Nuclear Receptor 1 8-31.

Western PS, Harry JL, Marshall Graves JA \& Sinclair AH 2000 Temperature-dependent sex determination in the American alligator: expression of SF1, WT1 and DAX1 during gonadogenesis. Gene 241 223-232.

Whitfield GK, Jurutka PW, Haussler CA \& Haussler MR 1999 Steroid hormone receptors: evolution, ligands, and molecular basis of biologic function. Fournal of Cellular Biochemistry. Supplement 32-33 $110-122$.

Wibbels T, Cowan J \& LeBoeuf R 1998 Temperature-dependent sex determination in the red-eared slider turtle, Trachemys scripta. Fournal of Experimental Zoology $281409-416$.

Willingham E, Baldwin R, Skipper JK \& Crews D 2000 Aromatase activity during embryogenesis in the brain and adrenal-kidney-gonad of the red-eared slider turtle, a species with temperature-dependent sex determination. General and Comparative Endocrinology 119 202-207.

Woods JE \& Erton LH 1978 The synthesis of estrogens in the gonads of the chick embryo. General and Comparative Endocrinology $\mathbf{3 6}$ $360-370$.

Yoshiura Y, Senthilkumaran B, Watanabe M, Oba Y, Kobayashi T \& Nagahama Y 2003 Synergistic expression of Ad4 BP/SF-1 and cytochrome P-450 aromatase (ovarian type) in the ovary of Nile tilapia, Oreochromis niloticus, during vitellogenesis suggests transcriptional interaction. Biology of Reproduction 68 1545-1553.

Zaborski P 1986 Temperature and estrogen dependent changes of sex phenotype and $\mathrm{H}-\mathrm{Y}$ antigen expression in gonads of a newt. Progress in Clinical and Biological Research 217A 163-169.

Received in final form 14 October 2005 Accepted 31 October 2005

Made available online as an Accepted preprint on 22 November 2005 